\title{
Riboflavin in Nutrition, Food Processing, and Analysis - A Review
}

\author{
Jennifer L. Golbach ${ }^{1}$, Steven C. Ricke ${ }^{2}$, Corliss A. O’Bryan² \& Philip G. Crandall ${ }^{2}$ \\ ${ }^{1}$ EPL Bio Analytical Services LLC, Niantic, IL, USA \\ ${ }^{2}$ Department of Food Science and Center for Food Safety, University of Arkansas, Fayetteville, AR 72704, USA \\ Correspondence: Steven C. Ricke, Center for Food Safety, Department of Food Science and Center for Food \\ Safety, University of Arkansas, Fayetteville, AR 72704, USA. Tel: 1-479-575-4678; Fax: 1-479-575-6936. \\ E-mail: sricke@uark.edu
}

Received: June 27, 2014 Accepted: July 27, 2014 Online Published: July 30, 2014

doi:10.5539/jfr.v3n6p23 URL: http://dx.doi.org/10.5539/jfr.v3n6p23

\begin{abstract}
Riboflavin is an essential micronutrient in the human diet. Because riboflavin is water soluble and not stored in appreciable amounts in the body, sources of riboflavin must be constantly consumed. In the United States many cereal grains are being fortified with riboflavin. In this review we briefly discuss the chemistry of riboflavin, the role of riboflavin in nutrition and health, effects of food processing and storage and means of measuring riboflavin in food and animal feeds.
\end{abstract}

Keywords: riboflavin, micronutrient, vitamin B1

\section{Introduction}

In 1912 Casimir Funk postulated the existence of an organic compound that could be extracted from the inner bran layer of rice removed during polishing this compund was useful in treating beriberi. He suggested that pellagra, scurvy and rickets were also caused by deficiencies of other factors that were organic in nature and that these organic compounds would all contain an amine group, and thus he coined the phrase "vital amines" for these factors (Funk, 1912). When it was determined that not all of the factors that prevented nutritional deficiencies were amines, the term was shortened to "vitamin" (Carpenter, 2003). McCollum and Simmonds (1916) concluded that there were two growth factors needed by rats on a restricted diet, a fat-soluble Factor A and a water-soluble Factor B, signaling the beginning of the scheme of naming vitamins for a letter of the alphabet before their chemistry had been worked out. Factor B was noted to be involved in protection from the neuritis effects of the disease known as pellagra (McCollum \& Simmonds, 1916). McCollum and Kennedy (1916) found that when Factor B was autoclaved it lost the ability to prevent neuritis, but it could still promote growth in rats; thus they hypothesized the existence of a second portion of Factor $\mathrm{B}$ that was heat stable. These factors were termed vitamin $\mathrm{B}_{1}$ (heat sensitive) and vitamin $\mathrm{B}_{2}$ (the heat stable factor). The heat stable $\mathrm{B}_{2}$ was purified and given the common name of riboflavin (Emmet \& Luros, 1920). The chemical name of riboflavin is 7 , 8-dimethyl-10-1'-D-ribityl-isoalloxazine, and it possesses a methyl group at positions 7 and 8 and a D-ribityl moiety at position 10 on the flavin ring (Eitenmiller \& Landen, 2000). Currently most commercial riboflavin is produced by microbial synthesis using selected strains of the bacterium Bacillus subtilis, the mold Ashbyagossypii, or the yeast Candida famata (Abbas \& Sibirny, 2011). Several reviews have discussed riboflavin production including the recent reviews by Fischer and Bacher (2010) and Hohmannand and Stahmann (2010), which cover biochemical pathways and the biotechnology of riboflavin synthesis, respectively. Abbas and Sibirny (2011) summarize the construction of flavin overproducers using the modern approach of metabolic engineering and present data on industrial production of riboflavin. Thus our review will not touch upon these subjects, but rather we will focus on the chemistry and reactions of riboflavin, its role in human metabolism and methods for measuring riboflavin in foods and feeds.

\section{Chemistry of Riboflavin}

\subsection{Forms of Riboflavin}

All derivatives of riboflavin are given the generic name of flavin. Flavin mononucleotide (FMN) and flavin adenine dinucleotide (FAD) are the major riboflavin derivatives and act as coenzymes for a large number of enzymes that catalyze oxidation-reduction reactions (Dennison, Kirk, Bach, Kokoczka, \& Heldman, 1977). Flavins are able to exist in several oxidation states as well as multiple ionic forms. Fully oxidized riboflavin 
(flavoquinone) is yellow, while the flavosemiquinone is red or blue depending upon $\mathrm{pH}$ and the flavohydroquinone is colorless (Rivlin, 2007).

\subsection{Riboflavin Reactions}

Riboflavin is readily oxidized or reduced which allows it to function equally well in oxidation of organic molecules and in transferring electrons in the respiratory chain. Both FMN and FAD serve as coenzymes for many oxidase and reductase enzymes including cytochrome $\mathrm{c}$ reductase, D- and L-amino acid oxidases, xanthine and aldehyde oxidase, succinic dehydrogenase, glucose oxidase and fumaric dehydrogenase (Massey, 2000). These versatile riboflavin derivatives are involved in a wide array of funtions including energy production; the metabolism of lipids, vitamins, minerals, and drugs; and may even function as antioxidants (Massey, 2000).

\subsection{Photosensitivity of Riboflavin}

The ability to donate and accept electrons also makes riboflavin susceptible to photooxidation. When irradiated under visible or UV light in the presence of oxygen, riboflavin can produce superoxide radicals, singlet oxygen, hydroxy radicals, and hydrogen peroxide (Choe, Huang, \& Min, 2005). This reaction with light causes the degradation of the nutritional value of riboflavin as well as off-flavor in foods (Huang, Choe, \& Min, 2004). The photooxidation of riboflavin involves either an electron transfer which gnerates a superoxide ion (type I) or an energy transfer that causes the formation of singlet $\mathrm{O}_{2}$ (type II) (Silva, Edwards, \& Pacheco, 1999).

Milk and milk products contain high levels of riboflavin and are thus prone to photooxidation. Riboflavin plays an important role in light-induced off-flavor in milk through the formation of both the superoxide ion and singlet oxygen (Min \& Boff, 2002). The presence of singlet oxygen in milk stored under light was confirmed by electron spin resonance spectroscopy (Bradley \& Min, 2003). There are two distinctive off-flavors produced in milk from riboflavin photooxidation. The first is known as "sunlight", which imparts a burnt and oxidized odor in milk. This off flavor is attributed to dimethyl disulfide and methional which are products of the riboflavin induced oxidation of sulfur containing amino acids such as methionine. After prolonged exposure to light, milk develops a "cardboard-like or metallic" flavor. This flavor develops because the riboflavin oxidation initiates lipid oxidation that produces off-flavor products such ashexanal, pentanal, ketones, alcohols, and hydrocarbons (Gaafar \& Gaber, 1992; Jung, Yoon, Lee, \& Min, 1998; Skibsted, 2000; Pereda et al., 2008; Yuwanti, Raharjo, Hastuti, \& Supriyadi, 2011).

Bhowmik and Sil (2004) examined reducing agents for retarding riboflavin photooxidation and found that when using visible light, reducing agents did not prevent the oxidation of riboflavin in aqueous solutions. Although they found that there was no interaction between riboflavin and the added reducing agents, the fluorescence of riboflavin was quenched in their presence, indicating that there was a light induced electron transfer from the reducing agent to the excited riboflavin dye (Bhowmik \& Sil, 2004).

\subsection{Reactions With Other Vitamins}

When riboflavin is exposed to light it absorbs energy from the light and in turn may use this energy to form reactive oxygen species which can cause a cascade of destruction of several vitamins including vitamin A, vitamin C, vitamin D, and vitamin E. Vitamin A loss increases with the length and intensity of light exposure, and was found to be greater for vitamin A added to milk than for native vitamin A (DeMan, 1981). Ascorbic acid (vitamin C) functions as an antioxidant and does not absorb visible light; however, it is rapidly photooxidized in the presence of riboflavin and oxygen (Rocchette et al., 2000). This photooxidation is partially controlled by light intensity, amount of riboflavin, amount of ascorbic acid, oxygen concentrations, $\mathrm{pH}$, temperature, and the presence of other compounds (Choe et al., 2005). Vitamin D is a normal fortificant in milk and is also destroyed by photooxidation when riboflavin is present (King \& Min, 1998; Li \& Min, 1998; Li, King, \& Min, 2000). Vitamin D can also be destroyed by triplet oxygen, a reaction that occurs both in the light and dark and is temperature-dependent (Li et al., 2000).

\section{Riboflavin in Food, Absorption and Transport}

Riboflavin is readily available in the human diet via sources such as milk and dairy products, eggs, liver, kidney, yeast extracts, and fortified cereals (Powers, 2003). A significant contribution of riboflavin is provided through milk consumption, but riboflavin is easily photooxidized and losses of as much as $70 \%$ of the riboflavin content can occur when milk is exposed to only 4 hours of ultra-violet light (Truswell \& Milne, 1998). Milk stored in opaque or other pigmented containers that do not let light through does not photooxidise as easily as that stored in clear containers. Animal sources have been found to provide a better source of riboflavin than natural plant sources (Murphy, 2003).

The recommended dietary allowance (RDA) of vitamins is defined as an amount that should be sufficient to 
meet the metabolic needs of at least $95 \%$ of the human population (Northrop-Clewes, 2004). Riboflavin requirement estimates are based on depletion/repletion studies which determine the minimum amount of riboflavin intake at which there is no significant excretion of the vitamin in the urine. These types of studies in humans show a correlation between the amount of riboflavin taken in and urinary excretion, with a sharp and continuous rise in excretion at intakes above $1 \mathrm{mg} / \mathrm{d}$ (Bender, 2002). Using this method the RDA for riboflavin has been calculated for adults to be 0.4 to $0.9 \mathrm{mg} / \mathrm{day}$ (Bender, 2002), with an additional $0.3 \mathrm{mg} / \mathrm{day}$ recommended during pregnancy and an additional $0.5 \mathrm{mg}$ /day recommended during breast feeding (Manore, 2000). However, nutritionists caution that urinary excretion of riboflavin is not sensitive enough when there are very low riboflavin intakes (Powers, 2003)

Riboflavin status in the body can also be measured using the erythrocyte (red cell) riboflavin pool to determine an estimate of intracellular riboflavin levels. Most of the riboflavin within the body is located in the cells especially the erythrocytes (McCormick, 1989). Flavin levels in the erythrocytes are also not influenced by the recent intake of riboflavin, so tests utilizing the erythrocytes give a more accurate indication of riboflavin status (McCormick, 1989). The glutathione reductase index, however, is considered a better test because the erythrocyte tests relies on a value of "tissue saturation" that is difficult to define and values vary between individuals (Bates, 1993).

The erythrocyte glutathione reductase test determines the ratio of enzyme activities with and without added FAD such that the poorer the riboflavin status the higher the activation coefficient: this "enzyme functional index" is often referred to as EGRAC (Erythrocyte Glutathione Reductase Activation Coefficient) (Powers, 2003). This is the most widely used assay to determine riboflavin tissue saturation because it uses washed red blood cells or whole blood which remain stable in frozen storage; only small amounts of blood are needed; it can discriminate differences in the normal range of values; and it can be used to measure tissue saturation over values that vary from severe deficiency to normal. The one disadvantage of this test is that does not measure riboflavin levels when glucose 6-phosphate dehydrogenase deficiency is present (Bates, 1993).

\subsection{Metabolism of Riboflavin}

Riboflavin plays many key roles including production of energy through the coenzyme activity of FAD in the respiratory chain and oxidation/reduction reactions that are mediated by flavin coenzymes. Glutathione is an important antioxidant which is produced in the glutathione peroxidase antioxidant system, which requires riboflavin (Villamor, Kupka, \& Fawzi, 2003). Approximately 50\% of the riboflavin found in plasma is free riboflavin, $44 \%$ is FAD, and the remainder is FMN (Bender, 2002).

\subsection{Absorption}

Very little free riboflavin is found in natural sources, most is present as FAD, and smaller amounts occur as FMN. These latter two forms are non-covalently-bound to enzymes and it appears that flavins that are covalently bound are not available for absorption (McCormick, 1972). However, somewhat larger amounts of free riboflavin are found in milk and eggs bound to specific binding proteins (Zanette, Monaco, Zanotti, \& Spadon, 1984). Before absorption of riboflavin derivatives (FAD and FMN) can occur, they must be hydrolyzed to riboflavin by phosphatases present in the brush border of the upper intestinal tract (Baker, 1995). Absorption is mediated by an active carrier with an apparent maximum of approximately $30 \mathrm{mg}$ of riboflavin per meal, since there is little additional absorption of riboflavin when supplemented in greater amounts (Jusko \& Levy, 1967; McCormick, 1989; Zempleni, Galloway, \& McCormick, 1996). After the riboflavin utilizes active transport to cross into the enterocyte membranes, it is transported to the liver and peripheral tissues in the portal and systemic circulations (Halsted, 2003), while excess amounts of riboflavin pass through in the urine and stool (Rivlin, 2007).

Many factors affect the absorption of riboflavin in the intestines. For instance, copper, zinc, iron, and manganese have been shown to chelate riboflavin and FMN and interfere with riboflavin absorption (Groff \& Gropper, 1999). Diets high in psyllium gum appear to decrease the rate of riboflavin absorption but apparently psyllium does not change the overall amount of riboflavin absorbed (Rivlin, 2007). Alcohol, on the other hand, lowers both the rate of absorption and the amount absorbed, and there are indications that recovering alcoholics respond better to vitamin supplements of riboflavin rather than dietary sources (Rivlin, 2007). There is increased absorption of riboflavin when there is food in the digestive tract possibly due to the length of time for the stomach to empty and transit time through the gastrointestinal tract increases the exposure time that riboflavin is in contact with the intestinal cells that absorb it (Rivlin, 2007). Studies performed with cultured Caco-2 human intestinal epithelial cells demonstrated that riboflavin uptake was not dependent on $\mathrm{Na}^{+}$or $\mathrm{pH}$ in these specific cells, and confrmed the existence of a carrier-mediated absorbtion process (Said \& Ma, 1994). 


\subsection{Excretion}

Riboflavin is water soluble, therefore excretion of excess amounts occurs mainly in the urine (Groff \& Gropper, 1999). Riboflavin bound with cysteine and histidine can also be found in the urine if it has been absorbed in that form by the gastrointestinal tract or if it is generated in body cells from the degradation of flavoenzymes such as succinate dehydrogenase and monoamine oxidase (Groff \& Gropper, 1999). Riboflavin intake in excess of 1.7 mg will appear within two hours after ingestion, coloring the urine to a brighter orange-yellow (Groff \& Gropper, 1999). Small amounts of free riboflavin may also be secreted into the bile which is subsequently found in the feces; riboflavin in the feces may also be a result of the metabolic processes of the intestinal flora (Groff \& Gropper, 1999).

\section{Functions of Riboflavin}

The primary function of riboflavin involves capturing energy from the fats, proteins and carbohydrates that make up the diet. Riboflavin is converted to the FAD complex which functions in the electron transport chain, the series of chemical reactions that derive energy from food (Massey, 2000). Riboflavin is also essential to the activation of other vitamins, including pyridoxine and folic acid (Pinto \& Rivlin, 2013). A riboflavin-binding protein (RBP) is involved in the development of chicken and mammalian fetuses (Murty \& Adiga, 1982; White \& Merrill, 1988). The RBP removes the riboflavin from the maternal circulation and deposits it in the oocyte or embryo; the ratio of riboflavin in the fetus as compared to the mother is 4:1 (Adiga, Subramanian, \& Karande, 2002). The flavoproteins also have a role as signal transducers in programmed cell death (Susin et al., 1999), and in the regulation of the biological clock as indicated by the role in reducing the effects of jet lag (Ishiwaka et al., 1999). In addition, flavoproteins have important functions in detoxifying aromatic polluntants in soil (Dagley, 1987), photosynthesis (Zanetti \& Aliverti, 1991), and repair of DNA damage (Jorns, Wang, \& Jordan, 1987). They also serve as the blue-light receptors responsible for plants growing towards the source of light (Briggs, Christie, Knieb, \& Salomon, 1999)

\section{Riboflavin Deficiencies}

Chronic riboflavin deficiency is very rare in the developed world because of the ready availability of a wide variety of foods that contain riboflavin (Bender, 2002). However, in parts of the world where rice or other unenriched cereals are the primary diet chronic deficiencies may exist (Lakshmi, 1998; Roe, 1991). Because the body has an efficient method of conserving and reusing tissue riboflavin, a deficiency in riboflavin is almost never fatal (Bender, 2002). Riboflavin deficiency also occurs in alcoholics due to decreased intake, decreased absorption, and impaired utilization of riboflavin (Heese et al., 2012). Persons who suffer from anorexia usually do not have an adequate riboflavin intake, and lactose intolerant individuals may also have deficiencies because they do not consume milk or other dairy products that are considered good sources of riboflavin. Very physically active people, such as athletes or those who do manual labor, may require more riboflavin, although no increase in tolerance or performance is seen when riboflavin supplements are given (Soares et al., 1993).

Glutathione reductase is a flavoprotein that is particularly sensitive to riboflavin depletion, and which functions as an important antioxidant in mammalian cells (Deponte, 2013). This enzyme plays important role in inhibiting the formation of cataracts in the eye (de La Rochette et al., 2000). Glutathione reductase activity is also important for red blood cells; in a deficiency the increased oxidative stress may cause lysis of red blood cells which may lead to anemia (Harmatz, Butensky, \& Lubin, 2003).

Deficiencies in riboflavin have long been linked with increased cancer risk (Rivlin, 1997). Riboflavin deficiency possibly increases carcinogenesis by increasing activation of carcinogens, particularly nitrosamines (Webster, Gawde, \& Bhattacharya, 1996). It has also been suggested that riboflavin deficiency may lessen effects of carcinogens. An isolated study in rats indicated that a deficiency of riboflavin led to an increase in DNA breakage when the rats were exposed to hepatocarcinogens, which in turn caused repair enzymes which contribute resistance to malignant transformations to be enhanced in the deficient animals (Powers, 2003). Additionally, applying riboflavin to the skin may increase the synthesis of melanin because of the stimulation of free-radicals, which increases the risk of skin cancer (Rivlin, 2007).

Studies in geographical areas of the world that have a high rate of malaria have shown that riboflavin-deficient human subjects are relatively resistant to malaria and have a lower parasite burden than those subjects that are adequately nourished (Bender, 2002; Rivlin, 2007). There are two proposed mechanisms for how this protection takes place. The malarial parasites require a relatively high level of riboflavin, and thus a decrease in riboflavin impairs the growth of parasites because they are not obtaining the required amounts of the vitamin. The second theory postualtes that because of the impaired antioxidant activity in erythrocytes, the erythrocyte cell membrane might be more fragile or have reduced membrane fluidity, thus exposing the parasites to the host's immune 
system at a more vulnerable stage which results in the production of antibodies. This is similar to the sickle cell trait which also protects against malaria (Bender, 2002; Rivlin, 2007; Bhaskaram, 2002).

Riboflavin deficiencies can be treated with oral doses of riboflavin up to $25 \mathrm{mg}$; doses greater than this amount will not be absorbed (Rivlin, 2002, 2007). Storage capacity for riboflavin in the tissues is presumably limited by the availability of proteins that provide binding sites for the flavins (Rivlin, 2007). Although consumption of mega-doses of riboflavin has not been shown to be toxic, there is a theoretical risk for the administration of riboflavin. Riboflavin has photosensitzing properties which may result in DNA degradation and an increase in the formation of lipid peroxides (Misra, Bajpai, Joshi, \& Hans 2001; Rivlin, 2002). When riboflavin forms an adduct with tryptophan, the level of photodegradation is accelerated.

Riboflavin sustained release floating capsules meant to delay release of riboflavin have been examined for the treatment of riboflavin deficiencies in people (El-Samaligy, El-Shakhs, Holail, \& Sabry, 2003). The capsules are prepared with a component such as sodium bicarbonate which releases $\mathrm{CO}_{2}$ in the intestinal tract and causes the capsule to rise to the top of the contents of the stomach. By having the riboflavin be available only towards the end of digestion, the passage rate is slowed to provide more time for riboflavin to be in contact with the small intestine (El-Samaligy et al., 2003). This study showed an increase of riboflavin concentration in the human subjects using the capsules that caused the vitamin to float to the top compared to the capsules that did not cause the vitamin to float to the top (El-Samaligy et al., 2003).

Riboflavin also has interactions with other B group vitamins. The effects of acute riboflavin deficiency on fetal development are similar to the effects of folate deficiency, suggesting a role for flavins in folate metabolism (Powers, 2003). Conversion of vitamin $\mathrm{B}_{6}$ to its active coenzyme form requires a FMN-dependent enzyme (McCormick, 1989).

\section{Effects of Food Processing}

Processing and storage of food can significantly impact the quantities of vitamins found in the diet, but these effects vary among the vitamins. The principal factors of processing and storage that influence vitamins are heat, moisture, oxygen, $\mathrm{pH}$, and light (Ottaway, 2002). These factors can be encountered during various processing methods such as milling, fermentation, germination, extrusion, and thermal processing (Reddy \& Love, 1999). These factors affect vitamins the same whether the vitamins are naturally occurring in the specific food or if they are added as a fortificant. However, the form in which a synthetic vitamin is added may enhance the stability of the vitamin (Ottaway, 2002). Riboflavin and riboflavin-phosphate are both stable to heat and atmospheric oxygen, especially in acidic media. However, riboflavin is especially sensitive to sunlight and to a slightly lesser extent, fluorescent light, particularly in liquids, and is also increasingly unstable at higher $\mathrm{pH}$ values (Ottaway, 2002). The destruction of riboflavin increases dramatically when oxygen is present during storage as well as when metal sulfates are present. Water activity also has an impact on riboflavin stability; during low moisture storage, almost $100 \%$ of the riboflavin content is retained, but the loss of riboflavin increases with the amount of water activity (Choe et al., 2005).

A study done by Prodanov, Sierra and Vidal-Valverde (2003) determined riboflavin loss in legumes during soaking and cooking. Soaking in sodium bicarbonate significantly decreased the riboflavin content of fava beans and chickpeas. However, lentils exhibited a marked increase of riboflavin content when soaked in citric acid, water, or sodium bicarbonate. The only decrease of the riboflavin content in lentils occurred when they were soaked in sodium bicarbonate and subsequently cooked. The increase of lentil riboflavin content was attributed to microbial activity in the lentil cover; immediately after hydration of the lentils, bacteria, mainly certain Lactobacillus species, were able to synthesize riboflavin (Prodanov et al., 2003). The cooking of meats has a significant effect on riboflavin. A study done by Lombardi-Bocca, Lanzi and Aguzzi (2005) demonstrated that when meat is cooked there is a significant loss of riboflavin. Thermal processing of soymilk apparently has no detectable effect on the riboflavin content of soymilk (Kwok, Shiu, Yeung, \& Niranjan, 1997).

\section{Food Fortification}

Fortification of foods with riboflavin is sometimes necessary when the foods commonly consumed in different parts of the world do not provide sufficient quantities of the vitamin to prevent deficiencies. There is strong evidence that significant human population subgroups have suboptimal intakes of certain vitamins and minerals some of which are iron, calcium, zinc, vitamin B1, B2, B6, D, and folate. Studies showed clear evidence that mandatory and voluntary addition of nutrients to foods can help ease the problem in at-risk populations (Flynn, Moreiras, Fletcher, Muller, \& Rolland, 2003). The most common food that is fortified with riboflavin are cereals (McNulty et al., 1996). Up to $200 \mathrm{mg} /$ serving of riboflavin is the determined maximum safe addition level for this particular vitamin (Flynn et al., 2003). There have been no adverse effects observed from riboflavin 
fortification; in fact, the upper intake range that would be considered safe is almost impossible to determine due to the absence of toxicity even at 100 times the RDA (Meltzer, Aro, Anderson, Koch, \& Alexander, 2003).

\section{Riboflavin Detection}

Riboflavin is one of the essential water soluble vitamins; it is synthesized by all plants and many microorganisms, (Bacher, Eberhardt, Fischer, Kis, \& Richter, 2000). Detection and determination of riboflavin in food and animal feed samples is important to ensure that the minimum amount of riboflavin required for normal growth is being obtained in the diet. Because so many different factors and processes can affect riboflavin and because many of the foods consumed are processed, quantification of vitamin concentration in foodstuffs can be important to prevent riboflavin deficiencies in certain populations. Quantification of riboflavin is also important for the cereal grain products that are often fortified with riboflavin to ensure people are receiving the recommended daily allowance (McNulty et al., 1996). Methods for quantification include physical, chemical, animal testing as well as microbiological techniques.

\subsection{Fluorometry}

Analysis of riboflavin by fluorometric methods is possible because riboflavin fluoresces strongly when exposed to light in the range of 440 to $500 \mathrm{~nm}$, and the intensity of the fluorescence is proportional to the concentration of riboflavin in the solution examined (Williams, Eakin, Beerstecher, \& Shive, 1950; Hodson \& Norris, 1939). The most common fluorimetric method for determining riboflavin content is the AOAC method for direct fluorometric detection based on the conversion of FAD and FMN to riboflavin giving a measurement of the total riboflavin in the sample (AOAC, 2012). Acid hydrolysis is completed by autoclaving the sample in $0.1 \mathrm{~N} \mathrm{HCl}$ for 30 minutes. To prepare the sample for this procedure and reduce any background fluorescence, the sample is acidified with glacial acetic acid and oxidized with potassium permanganate. After two minutes, the excess potassium permanganate is destroyed with hydrogen peroxide (Eitenmiller \& Landen, 2000).

Indirect fluorometry can also be used to determine riboflavin concentration. This method utilizes lumiflavin to quantitatively determine the amount of riboflavin. The lumiflavin is formed when the sample is irradiated under alkaline conditions. It fluoresces more strongly than free riboflavin, and it is chloroform soluble which provides a means of removing interfering fluorescent compounds from the sample matrix. This procedure is more sensitive than direct fluorometry of riboflavin due to the increased fluorescence of lumiflavin. Although this procedure is not commonly used in the U. S., it is able to eliminate sensitivity problems and poor chromatograms that are associated with the direct analysis of riboflavin (Eitenmiller \& Landen, 2000). Both of the fluorometric methods have some documented weaknesses. Interference from fluorescing impurities from the sample matrix leads to an overestimation of the total riboflavin content (Russell \& Vanderslice, 1992).

\subsection{High Performance Liquid Chromatography}

High performance liquid chromatography (HPLC) has many advantages. It can be developed for almost any pharmaceutical or biological matrix, it is sensitive, specific, rapid (Eitenmiller \& Landen, 2000), and can be used to conduct assays on multiple vitamins simultaneously (Russell, 2000). The drawbacks of this assay are that it requires relatively expensive equipment and trained personnel. In addition, the determination of naturally occurring vitamins is somewhat limited and it cannot be guaranteed that an HPLC analysis is able to account for all the active forms of a vitamin that would normally be quantified in more biologically-based assays, and HPLC may also underestimate vitamin content (Ball, 1994).

For HPLC detection, ultraviolet absorbance is probably the most common method followed by fluorescence and electrochemical detection. The fluorescence and electrochemical detection are generally used when physiochemical properties permit this type of detection and increased sensitivity and selectivity are desired. Refractive index can also be used, but it is not a common procedure because it lacks specificity and sensitivity (Russell, 2000). An interlaboratory comparison of HPLC and microbiological methods for total riboflavin revealed significant variability between the 13 labs that participated, with the most likely source of the variability apparently being the extraction and hydrolysis methods used by the different laboratories (Russell, 2000; van den Berg, van Schaik, Finglas, \& de Froidmont-Gortz, 1996).

\subsection{Immunoassays}

Immunoassays and protein-binding assays are also possible for the quantification of vitamins. These assays are as sensitive as the other methods and are less prone to interference. Large numbers of samples can be run using ELISAs and non-isotopic protein-binding assays that utilize microtiter plates. These assays do not have the problem of handling and disposing of radioactive waste (Ball, 1994). The immunoassays and protein-binding assays chemically or enzymatically extract the vitamins from the food matrix to ensure the riboflavin is in its 
free form before being run on the microtiter plate. The use of these assays depends on the reliability, applicability, and validation as well as the commercial availability of standardized kits (Ball, 1994). Efforts to develop high-affinity antibodies selective for riboflavin have met with limited success (Monroe, 1984), although recently Wang et al. (2013) have claimed development of a sensitive and specific polyclonal antibody for riboflavin. Natural binders are utilized in most assays, such as riboflavin-binding protein from chicken egg white (Fazekas, Menendez, \& Rivlin, 1974; Bashor \& Tillotson, 1978; Geun \& Meyerhoff, 1988).

\subsection{Microbiological Assays}

Microbiological assays are one of the more common ways of estimating vitamin concentrations in food samples, since they have the advantage of equipment, ready-made media commercially available, space, labor, materials, and time (Voigt \& Eitenmiller, 1985; Russell \& Vanderslice, 1992; Ball, 1994). An assay using Lactobacillus rhamnosus is the traditional means to determine riboflavin concentrations in samples; L. rhamnosus is a nonspore-forming rod that grows optimally between 15 and $45{ }^{\circ} \mathrm{C}$ and is somewhat fastidious in terms of nutritional requirements. Vitamin determination using microbiological methods is based on the nutritional requirement of the specified organism for the vitamin of interest. A basal medium provides all of the growth requirements for the organism except the vitamin being assayed. A growth response over time can be generated using a defined concentration range that will allow for an estimation of total or maximum growth. The total growth response is directly proportional to the amount of vitamin added to the medium. To determine the amount of vitamins present in the sample, the growth can be measured photometrically or the formation of metabolic products can be monitored (Voigt \& Eitenmiller, 1985).

A different microbial assay approach has been developed for the determination of riboflavin in samples that involves agar-diffusion rather than measurement of optical density (Salvetti, Celandroni, Ghelardi, Baggiani, \& Senesi, 2003). These researchers were able to measure riboflavin concentrations in biological samples using the bacterium Bacillus cereus. Only with the B. cereus mutant were the researchers successful in developing an agar-diffusion assay for riboflavin quantification, as other organisms tested were able to grow in a medium without riboflavin. The studies conducted with this approach found this assay to be highly reproducible, sensitive, rapid, inexpensive, and it can be applied to measure the amount of riboflavin in desired samples. This assay is considered a good candidate for the screening of bacteria growing on media that secrete riboflavin (Salvetti et al., 2003).

The riboflavin assay has been standardized for use with test tubes by AOAC (Ball, 1994), but this assay has the capability of being more user friendly by adaptation to microtiter plates. The microbiological folic acid assay using the same bacterium was successfully scaled down to microtiter plates (Horne \& Patterson, 1988). The microtiter plate assay was able to save time, labor, and supplies and was able to assay more samples at one time (Horne \& Patterson, 1988). In addition to the decreased assay time, microtiter plates are cost efficient as more trials can be conducted simultaneously with less expense of space and media compared to tubes (Voigt \& Eitenmiller, 1985; Newman \& Tsai, 1986). Golbach, Chalova, Woodward and Ricke (2007b) adapted the riboflavin tube assay to a microtiter plate assay. They found no significant difference between the tube assay and microtiter plate assay for a commercial maize sample and the microtiter assay reduced the amount of time required for sufficient bacterial growth response to generate linear standard curves from 16.5 to $10 \mathrm{~h}$ (Golbach et al., 2007b). The relatively long growth period (18 to $24 \mathrm{~h}$ ) required for the completion of the AOAC $L$. rhamnosus riboflavin tube assay is in part due to the significant lag phase (approximately $8 \mathrm{~h}$ ) that occurs during the standardized riboflavin assay (Golbach et al., 2007b). Therefore, the reduction of the lag phase and/or an increase in the growth rate could reduce the assay time. According to several authors (Brown, 1968; Reuter, 1985; Tharmaraj \& Shah, 2003), L. rhamnosus growth is favored by microaerophilic conditions. For optimum growth, reduced oxygen content and approximately $10 \% \mathrm{CO}_{2}$ is recommended (Reuter, 1985; Vescovo, Scolari, Orsi, Sinigaglia, \& Torriani, 1997). Therefore Golbach, Chalova, Kim, Woodward and Ricke (2007a) studied the growth responses of Lactobacillus rhamnosus to microaerophilic conditions produced by three different reducing agents, ascorbic acid, dithiothreitol and thioglycollate. It was determined that none of the reducing agents caused a further increase of optical density or had a significant effect on the growth rates. However, growth in an anaerobic chamber for $14 \mathrm{~h}$ produced a significantly higher optical density than growth under aerobic incubation conditions (Golbach et al., 2007a).

\section{Conclusions}

Riboflavin or its derivatives are found in a wide variety of foods, although milk and milk products make a particularly important contribution to the riboflavin intakes of populations in Western countries and the decline in the consumption of milk and milk products in Western countries may contribute to the poor riboflavin status 
reported in sections of the population, particularly young people. Riboflavin is generally stable during the heat processing and normal cooking of foods if light is excluded, and the alkaline conditions in which riboflavin is unstable are rarely encountered in foodstuffs. Nevertheless, in the United States non whole grain cereals are required to be fortified with riboflavin. The most common methods of measuring riboflavin in foods are the HPLC method and microbiological growth-based method. It is envisioned that as more is known about the Lactobacillus used for estimating riboflavin that genetic and molecular approaches could be used to develop a more precise assay response by cloning the key components involved in responding to riboflavin into other non-Lactobacillus microorganisms. This would have the potential of utilizing bacteria with a much faster growth rate with perhaps less stringent nutritional requirements. This would allow not only for easier cultivation but would permit faster bioassays to be conducted. Eventually biosensors could be developed which could potentially be even more robust and enable more routine utility as a riboflavin bioassay.

\section{References}

Abbas, C. A., \& Sibirny, A. A. (2011). Genetic control of biosynthesis and transport of riboflavin and flavin nucleotides and construction of robust biotechnological producers. Microbiology and Molecular Biology Reviews, 75, 321-360. http://dx.doi.org/10.1128/MMBR.00030-10

Adiga, P. R., Subramanian, S., \& Karande, A. A. (2002). Biology of riboflavin carrier protein-an update. Proceedings of the Indian National Science Academy Part B, Biological Sciences, 68, 1-28.

Agte, V. V., Chiplonkar, S. A., \& Gokhale, M. K. (1992). Interaction of riboflavin with zinc bioavailability. Annals of the New York Academy of Sciences, 669, 314-316. http://dx.doi.org/10.1111/j.1749-6632.1992.tb17111.x

AOAC. (2012). Official Methods of Analysis of AOAC International (19th ed.). Gaithersburg, MD: AOAC International.

Bacher, A., Eberhardt, S., Fischer, M., Kis, K., \& Richter, G. (2000). Biosynthesis of vitamin B2 (Riboflavin). Annual Review of Nutrition, 20, 153-167. http://dx.doi.org/10.1146/annurev.nutr.20.1.153

Baker, D. H. (1995). Vitamin bioavailability. In C. Ammerman, D. Baker \& A. Lewis (Eds.), Bioavailability of Nutrients for Animals: Amino Acids, Minerals, and Vitamins (pp. 399-431) Waltham, MA, USA: Academic Press, Inc. http://dx.doi.org/10.1016/B978-012056250-3/50044-5

Ball, G. F. M. (1994). Appraisal of analytical techniques. In G. F. M. Ball (Ed.) Vitamin Assays in Human Nutrition. (pp. 387-409). London: Chapman \& Hall. http://dx.doi.org/10.1007/978-1-4615-2061-0_9

Barile, M., Brizio, C., Valenti, D., De Virgilio, C., \& Passarella, S. (2000). The riboflavin/FAD cycle in rat liver mitochondria. European Journal of Biochemistry, 267, 4888-4900. http://dx.doi.org/10.1046/j.1432-1327.2000.01552.x

Bashor, M.M., \& Tillotson, J. A. (1978). Isolation of a riboflavin-binding apoproetein from chicken egg white and its use in a radioassay for urinary riboflavin. Federation Proceedings, 37, 672-672.

Bates, C. (1993). Riboflavin. International Journal for Vitamin and Nutrition Research, 63, 274-277.

Bender, D. A. (2002). The vitamins. In M. J. Gibney, S. A Lanham-New, A. Cassidy \& H. H. Vorster (Eds), Introduction to Human Nutrition (pp. 125-176). Oxford, UK: Blackwell Publishing.

Bhaskaram, P. (2002). Micronutrient malnutrition, infection, and immunity: an overview. Nutrition Reviews, 60, S40-S45. http://dx.doi.org/10.1301/00296640260130722

Bhowmik, B. B., \& Sil, A. (2004). Photoinduced interaction of riboflavin dye with different reducing agents in aqueous and liposome media. Chemistry and Physics, 127, 189-197.

Briggs, W. R., Christie, J. M., Knieb, E., \& Salomon, M. (1999). In S. Ghisla, P. Kroneck, P. Macheroux \& H. Sund (Eds.), Flavins and Flavoproteins 1999 (pp. 299-308), Berlin: Rudolf Weber Agency for Scientific Publications.

Brown, J. P. (1968). Anomalous anaerobic growth yields of Lactobacillus caseistrain 103 in complex medium. Applied Microbiology, 16, 805-807.

Carpenter, K. J. (2003). A short history of nutritional science: part 3 (1912-1944). Journal of Nutrition, 133, 3023-3032.

Cataldi, T. R. I., Nardiello, D., De Benedetto, G. E., \& Bufo, S. A. (2002). Optimizing separation conditions for riboflavin, flavin mononucleotide and flavin adenine dinucleotide in capillary zone electrophoresis with 
laser-induced fluorescence detection. $J \quad$ Chromatog A, 968, 229-239. http://dx.doi.org/10.1016/S0021-9673(02)00953-6

Choe, E., Huang, R., \& Min, D. B. (2005). Chemical reactions and stability of riboflavin in foods. Journal of Food Science, 70, R28-R36. http://dx.doi.org/10.1111/j.1365-2621.2005.tb09055.x

Dagley, S. (1987). Lessons from biodegradation. Annual Reviews in Microbiology, 41, 1-23. http://dx.doi.org/10.1146/annurev.mi.41.100187.000245

de La Rochette, A., Silva, E., Birlouez-Aragon, I., Mancini, M., Edwards, A-M., \& Morliere, P. (2000). Riboflavin photodegradation and photosensitizing effects are highly dependent on oxygen and ascorbate $\begin{array}{lllll}\text { concentrations. } & \text { Photochemistry }\end{array}$ http://dx.doi.org/10.1562/0031-8655(2000)072<0815:RPAPEA>2.0.CO;2

De Man, J. M. (1981). Light induced destruction of vitamin A in milk. Journal of Dairy Science, 64, $2031-2032$. http://dx.doi.org/10.3168/jds.S0022-0302(81)82806-8

Deponte, M. (2013). Glutathione catalysis and the reaction mechanisms of glutathione-dependent enzymes. Biochimica et Biophysica Acta, 1830, 3217-3266. http://dx.doi.org/10.1016/j.bbagen.2012.09.018

Dennison, D., Kirk, J., Bach, J., Kokoczka, P., \& Heldman, D. (1977). Storage stability of thiamin and riboflavin in a dehydrated food system. Journal of Food Processing and Preservation, 1, 43-54. http://dx.doi.org/10.1111/j.1745-4549.1977.tb00312.x

El Samaligy, M., El Shakhs, S. A., Holail, S. M., \& Sabry, N. A. (2003). Formulation and in-vivo investigation of riboflavin sustained release floating capsules. Egyptian Journal of Pharmaceutical Sciences, 44(1), 73-85.

Emmett, A. D., \& Luros, G. O. (1920). Water soluble vitamins, I. Are the antineuritic and the growth-promoting water soluble B vitamins the same? Journal of Biological Chemistry, 43, 265-288.

Eitenmiller, R. R., \& Landen Jr., W. O. (2000). Riboflavin. In W. O. Song, G. R. Beecher \& R. R. Eitenmiller (Eds), Modern Analytical Methodologies in Fat-and Water-Soluble Vitamins vol. 154 (pp. 253-289). New York: John Wiley \& Sons.

Fazekas, A. G., Menendez, C. E., \& Rivlin, R. S. (1974). Competitive protein binding assay for urinary riboflavin. Biochemical Medicine, 9, 167-176. http://dx.doi.org/10.1016/0006-2944(74)90049-0

Fischer, M., \& Bacher, A. (2010). Riboflavin biosynthesis, In L. Mander \& H. W. Liu (Eds.), Comprehensive natural products. II. Chemistry and biology, vol. 7 Cofactors (pp. 3-36). Philadelphia, PA: Elsevier.

Flynn, A., Moreiras, O., Fletcher, R. J., Muller, D. J. G., \& Rolland, V. (2003). Vitamins and minerals: A model for safe addition to foods. European Journal of Nutrition, 47, 118-130. http://dx.doi.org/10.1007/s00394-003-0391-9

Fogelholm, M. (2000). Metabolic Functions. In: Nutrition in Sport: Volume VII of the Encyclopedia of Sports Medicine, (pp. 266-271). Maughan, R.J., Ed, Blackwell Science Ltd., Oxford, UK.

Fox, J. B., \& Thayer, D. W. (1997). Radical oxidation of riboflavin. International Journal of Vitamin and Nutrition Research, 68(3), 174-180.

Funk, C. (1912). The etiology of deficiency diseases. Journal of State Medicine, 20, 341-368.

Gaafar, A. M., \& Gaber, F. L. (1992). Volatile flavor compounds of sunlight-exposed milk. Egyptian Journal of Dairy Science, 20, 111-115.

Geun, .S. C., \& Meyerhoff, M. E. (1988) Solid-phase enzyme-linked competitive binding assay for riboflavin. Analytical Biochemistry, 168, 216-227. http://dx.doi.org/10.1016/0003-2697(88)90031-0

Goff, J. P. (2004). Vitamins. In W. O. Reece (Ed.). Dukes' Physiology of Domestic Animals (12th ed.) (pp. 562-574) Ithaca, NY: Cornell University Press.

Golbach, J. L., Chalova, V. I., Kim, W. K., Woodward, C. L., \& Ricke, S. C. (2007a). Growth response of Lactobacillus rhamnosus to microaerophilic incubation and addition of reductants in a riboflavin microtiter plate assay. Journal of Rapid Methods and Automation in Microbiology, 15, 320-331. http://dx.doi.org/10.1111/j.1745-4581.2007.00104.x

Golbach, J. L., Chalova, V. I., Woodward, C. L., \& Ricke, S. C. (2007b). Adaptation of Lactobacillus rhamnosus riboflavin assay to microtiter plates. Journal of Food Composition and Analysis, 20, 568-574. http://dx.doi.org/10.1016/j.jfca.2007.03.012 
Groff, J. L., \& Gropper, S. S. (1999). Riboflavin (Vitamin B2). In J. L. Groff \& S. S. Gropper (Eds.) Advanced Nutrition and Human Metabolism (pp. 269-274). Belmont, CA: Wadsworth/Thomas Learning.

Halsted, C. H. (2003). Absorption of water-soluble vitamins. Current Opinion in Gastroenterology, 19, 113-117. http://dx.doi.org/10.1097/00001574-200303000-00003

Heese, P., Linnebank, M., Semmler, A., Muschler, M. A. N., Heberlein, A., Frieling, H., ... Hillemacher, T. (2012). Alterations of homocysteine serum levels during alcohol withdrawal are influenced by folate and riboflavin: results from the German Investigation on Neurobiology in Alcoholism (GINA). Alcohol and Alcoholism, 47, 497-500. http://dx.doi.org/10.1093/alcalc/ags058

Hodson, A. Z., \& Norris, L. C. (1939). A fluorometric method for determining the riboflavin content of foodstuffs. Journal of Biology and Chemistry, 131, 621-630.

Hohmann, H. P., \& Stahmann, K. P. (2010). Biotechnology of riboflavin production, In L. Mander \& H. W. (Eds), Comprehensive natural products. II. Chemistry and biology, vol. 7 Cofactors (pp. 115-139) Philadelphia, PA: Elsevier.

Hoppel, C. L., \& Tandler, B. (1990). Riboflavin deficiency. Progress in Clinical Biology Research, 321, 233-248.

Huang, R., Choe, E., \& Min, D. B. (2004). Effects of riboflavin photosensitized oxidation on the volatile compounds of soymilk. Journal of Food Science, 69, C733-C738. http://dx.doi.org/10.1111/j.1365-2621.2004.tb09925.x

Horne, D. W., \& Patterson, D. (1988). Lactobacillus casei microbiological assay of folic acid derivatives in 96-well microtiter plates. Clinical Chemistry, 34, 2357-2359.

Ishiwaka, T., Todo, T., Matsumoto, A., Tanimura, T., Togashi, S., \& Ueda, R. (1999). Flavins and Flavoproteins In S. Ghisla, P. Kroneck, P. Macheroux \& H. Sund (Eds.), Flavins and Flavoproteins 1999, (pp. 317-320), Berlin: Rudolf Weber Agency for Scientific Publications.

Jorns, M. S., Wang, B., \& Jordan, S. P. (1987). DNA repair catalyzed by Escherichia coli DNA photolyase containing only reduced flavin: elimination of the enzyme's second chromophore by reduction with sodium borohydride. Biochemistry, 26, 6810-6816. http://dx.doi.org/10.1021/bi00395a034

Jung, M. Y., Yoon, S. H., Lee, H. O., \& Min, D. B. (1998). Singlet oxygen and ascorbic acid effects on dimethyl disulfide and off-flavor in skim milk exposed to light. Journal of Food Science, 63, 408-412. http://dx.doi.org/10.1111/j.1365-2621.1998.tb15753.x

Jusko, W. J., \& Levy, G. (1967). Absorption, metabolism and excretion of riboflavin 5'-phosphate in man. Journal of Pharmaceutical Sciences, 56, 58-62. http://dx.doi.org/10.1002/jps.2600560112

King, J. M., \& Min, D. B. (1998). Riboflavin photosensitized singlet oxygen oxidation of vitamin D. Journal of Food Science, 63, 31-34. http://dx.doi.org/10.1111/j.1365-2621.1998.tb15669.x

King, J. M., \& Min, D. B. (2002). Riboflavin-photosensitized singlet oxygen oxidation product of vitamin D2. Journal of the American Oil Chemists Society, 79, 983-987. http://dx.doi.org/10.1007/s11746-002-0591-6

Lakshmi, A. V. (1998). Riboflavin metabolism-relevance to human nutrition. The Indian Journal of Medical Research, 108, 182-190.

Li, T. L., King, J. M., \& Min, D. B. (2000). Quenching mechanisms and kinetics of carotenoids in riboflavin photosensitized singlet oxygen oxidation of vitamin D2. Journal of Food Biochemistry, 24, 477-492. http://dx.doi.org/10.1111/j.1745-4514.2000.tb00717.x

Li, T. L., \& Min, D. B. (1998). Stability and photochemistry of vitamin D2 in model system. Journal of Food Science, 63, 413-417. http://dx.doi.org/10.1111/j.1365-2621.1998.tb15754.x

Lin, Y., Desbois, A., Jiang, S., \& Tou, S. T. (2004). Group B vitamins protect murine cerebellar granule cells from glutamate/NMDA toxicity. Neuropharmacology and Neurotoxicology, 15, 2241-2244.

Lombardi-Boccia, G., Lanzi, S., \& Aguzzi, A. (2005). Aspects of meat quality: trace elements and B vitamins in raw and cooked meats. Journal of Food Composition and Analysis, 18, 39-46. http://dx.doi.org/10.1016/j.jfca.2003.10.007

Manore, M. M. (2000). Effect of physical activity on thiamine, riboflavin, and vitamin B-6 requirements. American Journal of Clinical Nutrition, 72, 598S-606S.

Massey, V. (2000). The chemical and biological versatility of riboflavin. Biochemical Society Transactions, 28, 283-296. http://dx.doi.org/10.1042/0300-5127:0280283 
McCollum, E. V., \& Kennedy, C. (1916). The dietary factors operating in the production of polyneuritis. Journal of Biological Chemistry, 24, 491-502.

McCollum, E. V., \& Simmonds, N. (1916). The relation of the unidentified factors, the fat-soluble A, and water-soluble B, of the diet to the growth-promoting properties of milk. Journal of Biological Chemistry, 27, $33-43$.

McCormick, D. B. (1972). The fate of riboflavin in the mammal. Nutrition Review, 30, 75-79. http://dx.doi.org/10.1111/j.1753-4887.1972.tb03991.x

McCormick, D. B. (1989). Two interconnected B vitamins: riboflavin and pyridoxine. Physiological Reviews, 69, 1170-1198.

McNulty, H., Eaton-Evans, J., Cran, G., Woulahan, G., Boreham, C., Savage, J. M., ... Strain, J. J. (1996). Nutrients intakes and impact of fortified breakfast cereals in schoolchildren. Archives of Disease in Childhood, 75, 474-481. http://dx.doi.org/10.1136/adc.75.6.474

Meltzer, H. M., Aro, A., Anderson, N. L., Koch, B., \& Alexander, J. (2003). Risk analysis applied to food fortification. Public Health Nutrition, 6, 281-290. http://dx.doi.org/10.1079/PHN2002444

Min, D. B., \& Boff, J. M. (2002). Chemistry and reaction of oxygen in foods. Comprehensive Review in Food Science and Food Safety, 1, 58-72. http://dx.doi.org/10.1111/j.1541-4337.2002.tb00007.x

Monroe, D. (1984). Enzyme immunoassay. Analytical Chemistry, 56, 920A-931A. http://dx.doi.org/10.1021/ac00272a001

Misra, R. B., Bajpai, P. K., Joshi, P. C., \& Hans, R. K. (2001). An unusual photohaemolytic property of riboflavin. Food Chemistry and Toxicology, 39, 11-18. http://dx.doi.org/10.1016/S0278-6915(00)00078-8

Murphy, S. P. (2003). Animal source foods to improve micronutrient nutrition and humanfunction in developing countries. Journal of Nutrition, 133, 3932S-3935S.

Murty, C. V., \& Adiga, P. R. (1982). Pregnancy suppression by active immunization against gestation-specific riboflavin carrier protein. Science, 216, 191-193. http://dx.doi.org/10.1126/science.7063879

Newman, E. M., \& Tsai, J. F. (1986). Microbiological analysis of 5-formyltetrahydrofolic acid and other folates using an automatic 96-well plate reader. Analytical Biochemistry, 154, 509-515. http://dx.doi.org/10.1016/0003-2697(86)90023-0

Ottaway, P. B. (2002). The stability of vitamins during food processing. In J. K. Henry \& C. Chapman (Eds.). The Nutrition Handbook for Food Processors (pp. 247-264). Boca Raton, FL: CRC Press. http://dx.doi.org/10.1533/9781855736658.2.247

Pereda, J., Jaramillo, D. P., Quevedo, J. M., Ferragut, V., Guamisand, B., \& Trujillo, A. J. (2008). Characterization of volatile compounds in ultra-high-pressure homogenized milk. International Dairy Journal, 18, 826-834. http://dx.doi.org/10.1016/j.idairyj.2007.12.002

Perelson, A. M., \& Ellenbogen, L. (2002). Rationale for use of vitamin and mineral supplements. In C. D. Berdanier, J. T. Dwyer, E. B. Feldman (Eds.) Handbook of Nutrition and Food (pp. 1333-1361) Boca Raton, FL: CRC Press LLC.

Pinto, J. R., \& Rivlin, R. S. (2013). Riboflavin (vitamin B 2 ) In J. Zempleni \& J. W. Suttied (Eds.). Handbook of Vitamins (pp. 191-266). Boca Raton, FL: CRC Press.

Powers, H. J. (1995). Riboflavin-iron interactions with particular emphasis on the gastrointestinal tract. Proceedings of the Nutrition Society, 54, 509-517. http://dx.doi.org/10.1079/PNS19950019

Powers, H. J. (2003). Riboflavin (vitamin B-2) and health. American Journal of Clinical Nutrition, 77, 1352-1360.

Prodanov, M., Sierra, I., \& Vidal-Valverde, C. (2004). Influence of soaking and cooking on the thiamine, riboflavin and niacin contents of legumes. Food Chemistry, 84, 271-277. http://dx.doi.org/10.1016/S0308-8146(03)00211-5

Reddy, M. B., \& Love, M. (1999). The impact of food processing on the nutritional quality of vitamins and minerals. In L. S. Jackson, M. G. Knize \& J. N. Morgan (Eds.). Impact of Processing and Food Safety. vol. 495. (pp. 99-106). New York: Kluwer Academic/ Plenum Publishers. http://dx.doi.org/10.1007/978-1-4615-4853-9_7

Reuter, G. (1985). Elective and selective media for lactic acid bacteria. International Journal of Food 
Microbiology, 2, 55-68. http://dx.doi.org/10.1016/0168-1605(85)90057-1

Rivlin, R. S. (1973). Riboflavin and cancer: a review. Cancer Research, 33, 1977-1986.

Rivlin, R. S. (2002). Vitamin deficiencies. In C. D. Berndanier (Ed.), Handbook of Nutrition and Food, (pp. 1313-1332). Boca Raton: CRC Press.

Rivlin, R. S. (2007). Riboflavin (Vitamin B2). In R. B. Rucker, J. Zempleni, J. W. Suttieand \& D. B. McCormick (Eds.), The Handbook of Vitamins (pp. 255-273). New York: Marcel Dekker, Inc.

Rochette, A. D. L., Silva, E., Birlouez-Aragon, I., Mancini, M., Edwards, A. M., \& Morliere, P. (2000). Riboflavin photodegradation and photosensitizing effects are highly dependent on oxygen and ascorbate $\begin{array}{llll}\text { concentrations. Photochemistry and Photobiology, } & \text { 72, }\end{array}$ http://dx.doi.org/10.1562/0031-8655(2000)0720815RPAPEA2.0.CO2

Roe, D. A. (1991). Riboflavin deficiency: mucocutaneous signs of acute and chronic deficiency. Seminars in Dermatology, 10, 293-295.

Ross, N. S., \& Hansen, T. P. (1992). Riboflavin deficiency is associated with selective preservation of critical flavoenzyme-dependent metabolic pathways. Biofactors, 3, 185-190.

Rucker, R. (2000). Vitamins: overview and metabolic functions. In M. E. Gershwin (Ed.), Nutrition and Immunology: Principles and Practice ( $\mathrm{pp}$ 75-96). Totowa, NJ: Humana Press. http://dx.doi.org/10.1007/978-1-59259-709-3_7

Russell, L. F. (2012). Quantitative determination of water-soluble vitamins. In L. M. L. Nollet \& F. Toldra (Eds.), Food Analysis by HPLC (pp. 325-442). New York: Marcel Dekker, Inc.

Russell, L. F., \& Vanderslice, J. T. (1992). Comments on the standard fluorometric determination of riboflavin in foods and biological tissues. Food Chemistry, 43, 79-82. http://dx.doi.org/10.1016/0308-8146(92)90245-W

Said, H. M., \& Ma, T. Y. (1994). Mechanism of riboflavin uptake by Caco-2 human intestinal epithelial cells. American Journal of Physiology, 266, G15-G21.

Salvetti, S., Celandroni, F., Ghelardi, E., Baggiani, A., \& Senesi, S. (2003). Rapid determination of vitamin B2 secretion by bacteria growing on solid media. Journal of Applied Microbiology, 95, 1255-1260. http://dx.doi.org/10.1046/j.1365-2672.2003.02095.x

Sauberlich, H. E. (1980). Interactions of thiamine, riboflavin, and other B-vitamins. Annals of the New York Academy of Sciences, 355, 80-97. http://dx.doi.org/10.1111/j.1749-6632.1980.tb21329.x

Silva, E., Edwards, A-M., \& Pacheco, D. (1999). Visible light-induced photooxidation of glucose sensitized by riboflavin. Journal of Nutritional Biochemistry, 18, 181-185. http://dx.doi.org/10.1016/S0955-2863(98)00093-X

Skibsted, L. H. (2000). Light-induced changes in dairy products. Bulletin of the International Dairy Federation, 346, 4-9.

Soares, M. J., Satyanarayana, K., Bamji, M. S., Jacob, C. M., Ramana, Y. V., \& Rao. S. S. (1993). The effect of exercise on the riboflavin status of adult men. British Journal of Nutrition, 69, 541-551. http://dx.doi.org/10.1079/BJN19930054

Susin, S. A., Lorenzo, H. K., Zamzami, N., Marzo, I., Snow, B. E., Brothers, G. M., ... Kroemer, G. (1999) Molecular characterization of mitochondrial apoptosis-inducing factor. Nature (London), 397, 441-445. http://dx.doi.org/10.1038/17135

Tharmaraj, N., \& Shah, N. P. (2003). Selective enumeration of Lactobacillus delbrueckii ssp. bulgaricus, Streptococcus thermophilus, Lactobacillus acidophilus, Bifidobacteria, Lactobacillus casei, Lactobacillus rhamnosus, and Propionibacteria. Journal of Dairy Science, 86, 2288-2296. http://dx.doi.org/10.3168/jds.S0022-0302(03)73821-1

Truswell, S., \& Milne, R. (2002). The B vitamins. In J. Mann \& A. S. Truswell (Eds.). Essentials of human nutrition (2nd ed.) (pp. 209-230). Oxford, UK: Oxford University Press.

Ullegaddi, R., Powers, H. J., \& Gariballa, S. E. (2004). B-group vitamin supplementation mitigates oxidative damage after acute ischaemic stroke. Clinical Science, 107, 477-484. http://dx.doi.org/10.1042/CS20040134

van den Berg, H., van Schaik, F., Finglas, P. M., \& de Froidmont-Gortz, I. (1996). Third EU MAT intercomparison on methods for the determination of vitamins B1, B2, and B6 in food. Food Chemistry, 57, 
101-108. http://dx.doi.org/10.1016/0308-8146(96)00145-8

Vescovo, M., Scolari, G., Orsi, C., Sinigaglia, M., \& Torriani, S. (1997). Combined effects of Lactobacillus casei inoculum, modified atmosphere packaging and storage temperature in controlling Aeromonashydrophila in ready-to-use vegetables. International Journal of Food Science and Technology, 32, 411-419. http://dx.doi.org/10.1046/j.1365-2621.1997.00121.x

Villamor, E., Kupka, R., \& Fawzi, W. (2003). Vitamins. In W. A. Walker, J. B. Watkins \& C. Duggan (Eds.) (pp. 111-133). Nutrition in Pediatrics: Basic Science and Clinical Applications (3rd Edition). Hamilton, Ontario, BC: Decker, Inc.

Voigt, M. N., \& Eitenmiller, R. R. (1985). Microbiological assays. In J. Augustin, B. Klein, D. Becker \& P. B. Venugopal (Eds.). Methods of Vitamin Assay. (pp. 43-63). New York: John Wiley \& Sons, Inc.

Wang, P., Yin, Y., Eremin, S. A., Rybakov, V. B., Zhang, T., Xu, Z., ... Xi, R. (2013). Indirect competitive immunoassay for detection of vitamin B2 in foods and pharmaceuticals. Journal of Agricultural and Food Chemistry, 61, 7048-7054. http://dx.doi.org/10.1021/jf401078t

Webster, R. P., Gawde, M. D., \& Bhattacharya, R. K. (1996). Modulation of carcinogen-induced DNA damage and repair enzyme activity by dietary riboflavin. Cancer Letters, 98, 129-135. http://dx.doi.org/10.1016/0304-3835(95)04011-0

White, H. B., \& Merrill, A. H. Jr. (1988). Riboflavin-binding proteins. Annual Reviews in Nutrition, 8, 279-299. http://dx.doi.org/10.1146/annurev.nu.08.070188.001431

Williams, R. J., Eakin, R. E., Beerstecher, E., \& Shive, W. (1950). The Biochemistry of B vitamins. New York, NY: Reinhold Publishing Corporation.

Yuwanti, S., Raharjo, S., Hastuti, P., \& Supriyadi, Y. (2011). Inhibition of riboflavin photosensitized off-flavour in milk products with $\mathrm{O} / \mathrm{W}$ micro emulsion containing Astaxanthin and $\alpha$-tocopherol. International Food Research Journal, 18, 1375-1379.

Zanette, D., Monaco, H. L., Zanotti, G., \& Spadon, P. (1984).Crystallisation of hen egg white riboflavin-binding protein. Journal of Molecular Biology, 180, 1185-1187. http://dx.doi.org/10.1016/0022-2836(84)90278-X

Zanetti, G., \& Aliverti, A. (1991) Ferredoxin: NADP $^{+}$oxidoreductase. In F. Müller (Ed.), Chemistry and Biochemistry of Flavoenzymes, vol II, (pp. 305-315). Boca Raton, FL: CRC Press.

\section{Copyrights}

Copyright for this article is retained by the author(s), with first publication rights granted to the journal.

This is an open-access article distributed under the terms and conditions of the Creative Commons Attribution license (http://creativecommons.org/licenses/by/3.0/). 